\section{Highlights am Eröffnungsabend DLT 2017 | LINZ}

Mittwoch, 11. Oktober 2017, 17:45 21:00 Uhr

- Verleihung ÖGUM-Ehrenmitgliedschaft an Prof. Dr. Reinhard Graf
- Dussik Lecture von Prof. Dr. Reinhard Graf: „30 000 Jahre Hüftgelenk, 30 Jahre Hüftultraschall“.

- Eröffnungsvortrag von Prof. Dr. Thomas Hildebrandt (Leibniz-Institut für Zoo- und Wildtierforschung Berlin): „Ultrasonografie vom Oktopus bis zum Elefant“"

- Get-together in der Industrieausstellung 